\title{
The use of cinacalcet hinders the diagnosis of parathyroid carcinoma in a chronic dialysis patient: a case report
}

\author{
Daisuke Takada ${ }^{1,2^{*}}$, Tatsuo Tsukamoto ${ }^{1,2}$, Miho Fuse ${ }^{3}$, Shinpei Kada ${ }^{3}$ and Motoko Yanagita ${ }^{1}$
}

\begin{abstract}
Background: Secondary hyperparathyroidism (SHPT) is a common complication in patients receiving chronic dialysis therapy. Although cinacalcet can control parathyroid function and bone turnover, preventing ectopic calcification remains challenging. Cinacalcet can also suppress PTH secretion due to parathyroid carcinoma in the same way as it does for parathyroid hyperplasia in the uremic condition. We present a case of parathyroid carcinoma partially controlled by cinacalcet, in which tumorous calcinosis was successfully resolved by total parathyroidectomy.

Case presentation: A female patient in her forties who had received dialysis for 12 years was referred to our hospital for painful ectopic calcifications on her right hip joint and both knees. Although she had been treated with alfacalcidol and cinacalcet for 2 years, this therapy had been discontinued 6 months earlier as a result of hypercalcemia. The patient exhibited normocalcemia $(2.37 \mathrm{mmol} / \mathrm{L})$ and hyperphosphatemia $(2.42 \mathrm{mmol} / \mathrm{L})$ with elevated intact parathyroid hormone $(707,000 \mu \mathrm{g} / \mathrm{L})$. Ultrasonography revealed an enlarged parathyroid gland on the left lower side of the thyroid gland. The otolaryngologist surgeons had to perform an en bloc excision to remove this parathyroid gland because of tight adhesions. Histological examination revealed that parathyroid cells had invaded the surrounding skeletal muscle through fibrous capsules, consistent with parathyroid carcinoma. Her joint pain disappeared 2 weeks after parathyroidectomy, and the tumorous calcinosis had largely resolved after 1 year.
\end{abstract}

Conclusions: Parathyroid carcinoma is a rare cause of hyperparathyroidism in end-stage kidney disease. Our case indicates that the use of cinacalcet hinders the diagnosis of parathyroid carcinoma in a chronic dialysis patient. When uncontrolled hypercalcemia and/or hyperphosphathemia develop during cinacalcet administration, parathyroidectomy should be considered to prevent a vicious exacerbation of ectopic calcification.

Keywords: Cinacalcet, Parathyroid carcinoma, Hemodialysis, Secondary hyperparathyroidism, Ectopic calcification, Case report

\section{Background}

Secondary hyperparathyroidism (SHPT) is a common complication in patients undergoing chronic dialysis therapy. A recent medical advance has enabled suppression of the parathyroid function using cinacalcet (a calcimimetic drug). Combined with vitamin $\mathrm{D}$, cinacalcet has successfully controls parathyroid function and bone turnover in many SHPT patients. Nevertheless, preventing ectopic

\footnotetext{
* Correspondence: daisuke.gaotian@gmail.com

'Department of Nephrology, Kyoto University Graduate School of Medicine,

54 Shogoin Kawahara-cho, Sakyo, Kyoto, Japan

2Department of Nephrology \& Dialysis, Kitano Hospital, The Tazuke Kofukai

Medical Research Institute, Osaka, Japan

Full list of author information is available at the end of the article
}

calcification, such as tumorous calcinosis and vascular calcification, remains a challenge [1]. These two conditions can be caused by an excess load of calcium and phosphate into the soft tissue, including the blood vessels associated with a trans-differentiation of vascular smooth muscle cells and fibroblasts to the osteoblastic phenotype in the uremic condition [2,3]. Since a non-calcium-containing phosphate binder can suppress the progression of calcification, ensuring a negative balance of calcium and phosphate in the body to reduce the load into the soft tissue is a reasonable therapeutic strategy $[4,5]$. There remains a limitation in the cinacalcet and vitamin D combination therapy to control SHPT, however, especially in cases with severe ectopic calcification. Parathyroidectomy 
(PTx) could be considered the final choice to resolve such issues $[6,7]$.

Parathyroid carcinoma is a rare cause of hyperparathyroidism [8]. The use of cinacalcet to treat hypercalcemia due to parathyroid carcinoma has recently been reported [9]. Here we present a case of parathyroid carcinoma partially controlled by cinacalcet, in which the tumorous calcinosis was successfully resolved by total PTx.

\section{Case presentation}

A female patient in her forties who had received regular hemodialysis ( $4 \mathrm{~h}, 3$ times a week) for 12 years with good adherence was referred to our hospital for multiple ectopic calcifications. The cause of her end-stage kidney disease was chronic glomerulonephritis (membranoproliferative glomerulonephritis). For 2 months she had experienced progressive pain in her right hip joint and left knee while walking. X-ray examinations revealed massive calcifications in these regions (Fig. 1a). Although her SHPT was well controlled with an adequate intact parathyroid hormone (iPTH) level, her calcium level had gradually increased (Fig. 2). Although she had been treated daily with $0.5 \mu \mathrm{g}$ alfacalcidol and $50 \mathrm{mg}$ cinacalcet for 2 years, this treatment had been discontinued 6 months earlier due to hypercalcemia and hyperphosphatemia. Calcium carbonate and lanthanum carbonate were used as a phosphate binder. Even after the calcium carbonate was discontinued, she remained hypercalcemic and eventually developed joint pain. Her iPTH level increased another 500,000 $\mu \mathrm{g} / \mathrm{L}$ before the referral. She also had unstable angina, and had received percutaneous coronary intervention with stenting for noticeably calcified coronary arteries. She had also been prescribed telmisartan, trandopril, sodium polystyrene sulfonate, aspirin, clopidogrel sulfate, eicosapentaenoic acid, omeprazole, and pravastatin.

On admission, the patient was $158.5 \mathrm{~cm}$ tall and weighed $49 \mathrm{~kg}$. Her blood pressure was 144/88 $\mathrm{mmHg}$. She had no palpable neck masses. Laboratory findings were as follows: calcium (Ca) $2.22 \mathrm{mmol} / \mathrm{L}$; inorganic phosphate (iP) $2.42 \mathrm{mg} / \mathrm{dL}$; alkaline phosphatase (ALP) $248 \mathrm{U} / \mathrm{L}$; and iPTH 707,000 $\mu \mathrm{g} / \mathrm{L}$ (Table 1). Ultrasonography of the neck showed an enlarged parathyroid gland on the left lower side of the thyroid with a long axis of $21 \mathrm{~mm}$. No other parathyroid glands were identified by ultrasonography (Fig. 1c). Computed tomography of the chest detected no ectopic parathyroid in the mediastinum or lung.
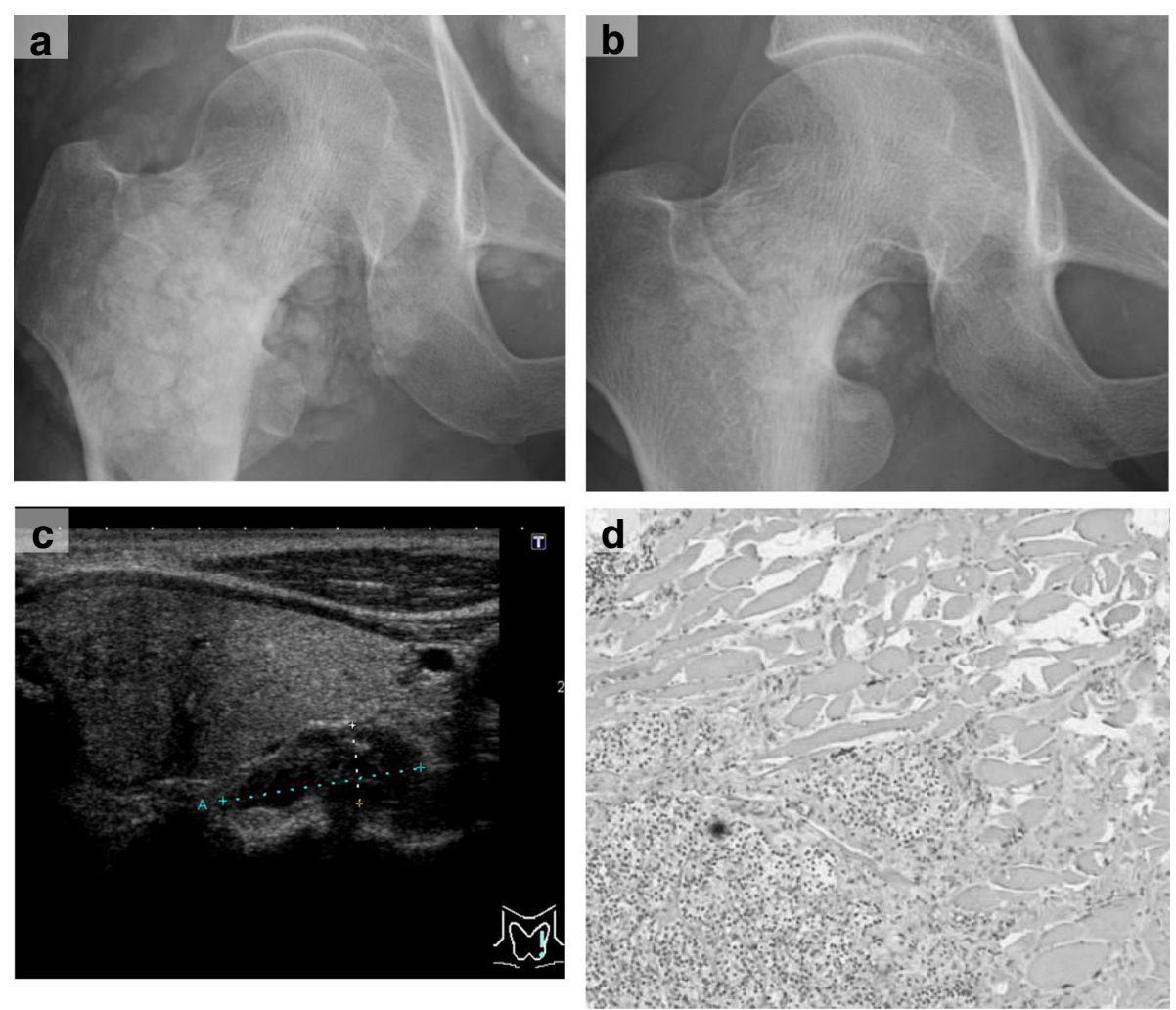

Fig. 1 Images. Panel $\mathbf{a}$ and $\mathbf{b}$; X-ray images of the right hip joint before (a) and after 6 months of total parathyroidectomy (b). Note that the massive calcifications around the right hip joint mostly disappeared after parathyroidectomy. Panel c; An enlarged parathyroid gland at the left lower side of the thyroid with a long axis of $21 \mathrm{~mm}$, near the muscle layer of the esophagus. Panel $\mathbf{d}$; Structural atypia in histological findings of the resected parathyroid gland at low $(\times 40)$ magnification 


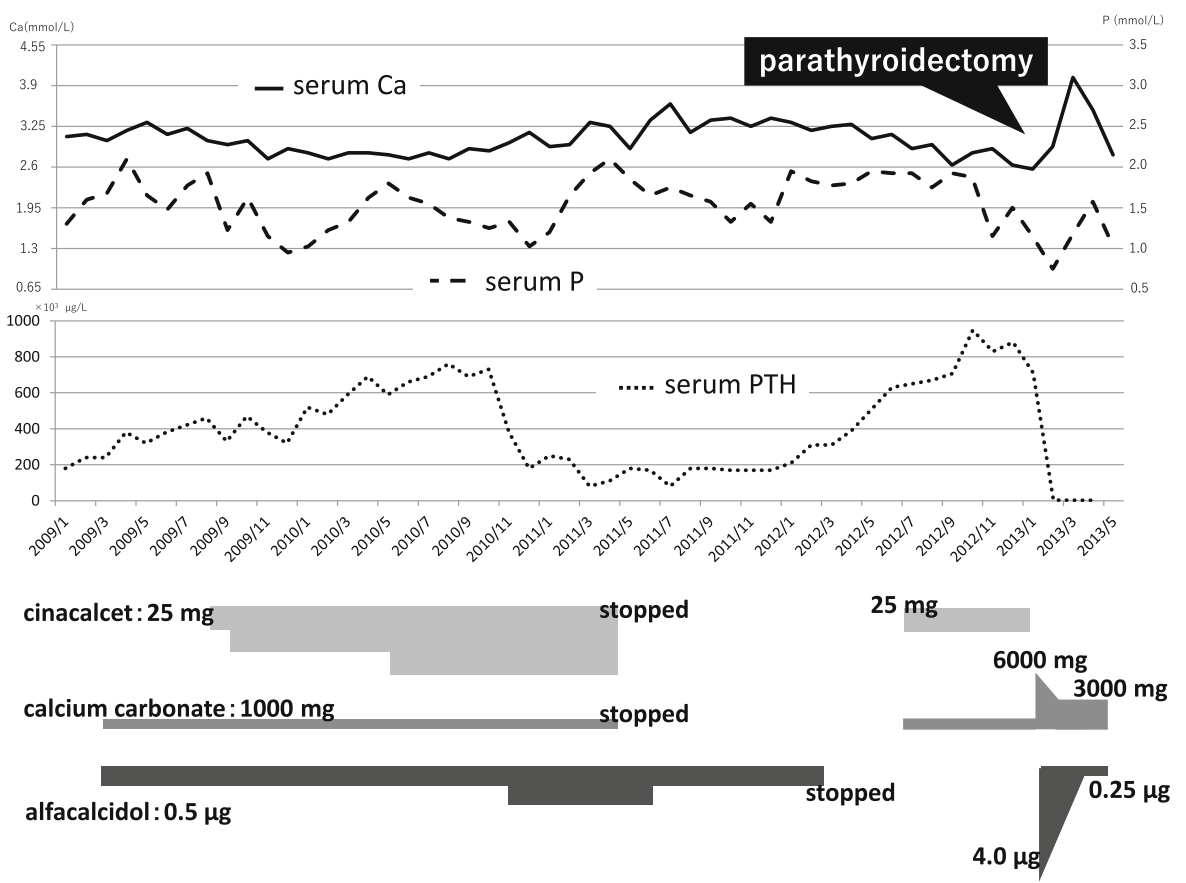

Fig. 2 Clinical course of laboratory data (serum calcium, phosphorus, and intact-parathyroid hormone) and medication before and after parathyroidectomy

We resected one large nodule and three normal-size parathyroid glands. As the largest gland had macroscopically invaded the left sympathetic nerve and clearly invaded muscle layer of the esophagus, we employed an en bloc excision. Histopathological analysis revealed that the parathyroid cells had contiguously invaded beyond the fibrous capsules into the surrounding skeletal muscle tissue (Fig. 1d). Thus, a diagnosis of parathyroid carcinoma was made.

Two weeks after the surgery, the patient's pain while walking had disappeared. To prevent postoperative hungry bone syndrome, calcium carbonate and alfacalcidol were administered for 2 months and then tapered off. $\mathrm{X}$-ray films showed a significant decrease in the tumoral calcinosis of the right hip joint and left knee after 3 months (Fig. 1b). Her chest pain during mild exercise disappeared. Her phosphate level was controlled below $1.94 \mathrm{mmol} / \mathrm{L}$ with a non-calcium-containing phosphate binder and longer dialysis time $(4.5-5.0 \mathrm{~h})$. Her iPTH level was 0 to $2000 \mu \mathrm{g} / \mathrm{L}$ under a relatively low calcium level $(2.00-2.12 \mathrm{mmol} / \mathrm{L})$, indicating that a total PTx was successfully achieved in this case.

\section{Discussion}

This case clearly indicated that the use of cinacalcet hinders the diagnosis of parathyroid carcinoma in a chronic dialysis patient. Cinacalcet is a calcimimetic drug that reduces PTH secretion by increasing the sensitivity of the calcium-sensing receptor (Ca-SR), which is specifically expressed in parathyroid cells $[10,11]$. Cinacalcet affects parathyroid adenoma and carcinoma, which express $\mathrm{Ca}-\mathrm{SR}$ on the cell surface, decreases the Ca level, and suppresses tumor growth $[9,12,13]$. Although cinacalcet is used extensively in the treatment of SHPT in chronic dialysis patients worldwide, clinical trials have not determined if cinacalcet would reduce cardiovascular events and improve mortality $[14,15]$.

Parathyroid carcinoma accounts for between $0.5 \%$ and $5 \%$ of all cases of primary hyperthyroidism [16, 17]. Approximately 700 parathyroid carcinoma cases have been reported, 20 of which occurred in chronic dialysis patients [16]. A Japanese retrospective study reported $3.14 \%$ parathyroid carcinomas in 826 parathyroidectomies [18]. As it is difficult to distinguish parathyroid carcinoma from parathyroid hyperplasia (which is the most common cause of SHPT) by routine image diagnosis, cinacalcet might cause a delay in the diagnosis of parathyroid carcinoma when it is used to control the PTH level in chronic dialysis patients.

Classically, the clinical features of parathyroid carcinoma include hypercalcemia, palpable neck mass, high serum PTH, and osteitis fibrosa cystica [19-21]. The principle histological features were reported by Castleman et al. to be: 1) a trabecular pattern, 2) mitotic figures, 3) thick fibrous bands, and 4) capsular and blood vessel invasion [22]. Since these features have also occasionally been noted in parathyroid adenoma and hyperplasia, two criteria were added later; the first is the local invasion of contiguous structures, and the second is lymph node or distant metastasis [23]. Our case did not 
Table 1 Laboratory data on admission

\begin{tabular}{lll}
\hline Complete blood count & & \\
White blood cell & 8600 & $/ \mu \mathrm{L}$ \\
Red blood cell & $403 \times 10^{4}$ & $/ \mu \mathrm{L}$ \\
Hemoglobin & 102 & $\mathrm{~g} / \mathrm{L}$ \\
Platelet & $27.1 \times 10^{4}$ & $/ \mu \mathrm{L}$ \\
Blood chemistry & & \\
Aspartate aminotransferase & 13 & $\mathrm{IU} / \mathrm{L}$ \\
Alanine aminotransferase & 5 & $\mathrm{IU} / \mathrm{L}$ \\
Lactate dehydrogenase & 188 & $\mathrm{IU} / \mathrm{L}$ \\
Alkaline phosphatase. & 284 & $\mathrm{IU} / \mathrm{L}$ \\
Y-glutamyltransferase & 10 & $\mathrm{IU} / \mathrm{L}$ \\
Total protein & 72 & $\mathrm{~g} / \mathrm{L}$ \\
Albumin & 34 & $\mathrm{~g} / \mathrm{L}$ \\
Blood urea nitrogen & 23.6 & $\mathrm{mmol} / \mathrm{L}$ \\
Uric acid & 434 & $\mathrm{\mu mol} / \mathrm{L}$ \\
Creatinine & 910 & $\mathrm{\mu mol} / \mathrm{L}$ \\
Sodium & 136 & $\mathrm{mmol} / \mathrm{L}$ \\
Potassium & 6.6 & $\mathrm{mmol} / \mathrm{L}$ \\
Chloride & 97 & $\mathrm{mmol} / \mathrm{L}$ \\
Calcium & 2.22 & $\mathrm{mmol} / \mathrm{L}$ \\
Phosphorus & 2.42 & $\mathrm{mmol} / \mathrm{L}$ \\
Magnesium & 0.99 & $\mathrm{mmol} / \mathrm{L}$ \\
C-reactive protein & 2000 & $\mathrm{Hg} / \mathrm{L}$ \\
Intact parathyroid hormone & 707,000 & $\mathrm{\mu g} / \mathrm{L}$ \\
Bone type alkaline phosphatase & 18.6 & $\mathrm{IU} / \mathrm{L}$ \\
Tartrate-resistant acid phosphatase $5 \mathrm{~b}$ & $\mathrm{mU} / \mathrm{dL}$ \\
\hline
\end{tabular}

have the typical clinical features described above, although the parathyroid cells invaded beyond the fibrous capsules pathologically and spread into the surrounding muscle also macroscopically, resulting in tight adhesion. Indeed, we had to perform an en bloc excision to resect the tumor during surgery. As the patient had not undergone treatment with other interventions for her parathyroid gland (such as percutaneous ethanol injection therapy), which could be a cause of secondary parathyromatosis, the surgical and histological findings strongly support the diagnosis of the largest parathyroid gland with carcinoma [24-26]. The recurrence rate for parathyroid carcinoma is reported to be 27,82 , and $91 \%$ after 1,5 , and 10 years, respectively [27]. Thus, the iPTH level should be monitored in order to ensure early detection of a recurrence.

A non-calcium-containing phosphate binder can suppress the progression of ectopic calcification, such as vascular calcification and tumorous calcinosis [5]. The combination of cinacalcet with Vitamin D might, however, lead to a decrease in bone turnover as a result of the decrease in PTH. Under these conditions, hypercalcemia with hyperphosphatemia due to the decreased buffering effect of bone could result in a positive load of calcium and phosphate into the soft tissue, resulting in ectopic calcification [28]. PTx can trigger hungry bone syndrome, which accelerates the draw of calcium and phosphate from the lesions of ectopic calcification sites and squeezes them into the bone [4].

In our case, the PTx allowed us to both treat the ectopic calcification and diagnose it as parathyroid carcinoma, and the serum calcium and PTH dropped when parathyroid carcinoma was removed. The iPTH value of SHPT patients who should be treated with PTx is recommended as $500,000 \mu \mathrm{g} / \mathrm{L}$ by the Japanese guideline [7]. Most symptomatic patients who receive chronic dialysis and who undergo PTx have a serum iPTH level of more than $800,000 \mu \mathrm{g} / \mathrm{L}$ [29]. Asymptomatic patients are, however, commonly referred for parathyroidectomy when they have a sustained PTH of more than $1000,000 \mu \mathrm{g} / \mathrm{L}[7,30]$. Indeed, cinacalcet came on the market in Japan in 2008, and the number of PTx in Japan decreased strikingly as a result $[15,18,31]$. Earlier PTx should be considered before a vicious exacerbation of ectopic calcification. Further study is required to determine the new indications of PTx in patients receiving chronic dialysis therapy and cinacalcet treatment.

\section{Conclusions}

We successfully treated a chronic dialysis patient for parathyroid carcinoma with tumoral calcinosis by total PTx. The use of cinacalcet hinders the diagnosis of parathyroid carcinoma in a chronic dialysis patient.

\section{Abbreviations \\ ALP: alkaline phosphatase; Ca: calcium; Ca-SR: calcium-sensing receptor; iP: inorganic phosphate; IPTH: intact parathyroid hormone; \\ PTx: parathyroidectomy; SHPT: secondary hyperparathyroidism}

\section{Acknowledgements}

We thank Dr. Yoshiki Mikami (Department of Pathology, Kyoto University Graduate School of Medicine) for helpful discussion about the histopathology of resected parathyroid tissue.

\section{Funding}

None.

Availability of data and materials

Records and data pertaining to this case are in the patient's secure medical records in the Kyoto University Hospital.

\section{Authors' contributions}

DT was an attending doctor for this patient under the supervision of $T$, and wrote this paper. SK and MF performed total parathyroidectomy. MY helped DT draft the manuscript. All authors discussed the results and implications,

commented on the manuscript at all stages, and approved the final manuscript.

Ethics approval and consent to participate

Not applicable. 


\section{Consent for publication}

Written informed consent was obtained from the patient, as well as for publication of this case report and any accompanying images.

\section{Competing interests}

The authors declare that they have no competing interests.

\section{Publisher's Note}

Springer Nature remains neutral with regard to jurisdictional claims in published maps and institutional affiliations.

\section{Author details}

'Department of Nephrology, Kyoto University Graduate School of Medicine, 54 Shogoin Kawahara-cho, Sakyo, Kyoto, Japan. ${ }^{2}$ Department of Nephrology \& Dialysis, Kitano Hospital, The Tazuke Kofukai Medical Research Institute, Osaka, Japan. ${ }^{3}$ Department of Otorhinolaryngology, Kyoto University Graduate School of Medicine, 54 Shogoin-Kawahara-cho, Sakyo-ku, Kyoto 606-8507, Japan.

Received: 15 December 2016 Accepted: 28 September 2017 Published online: 18 October 2017

\section{References}

1. Goodman WG, Goldin J, Kuizon BD, Yoon C, Gales B, Sider D, Wang Y, Chung J, Emerick A, Greaser L, et al. Coronary-artery calcification in young adults with end-stage renal disease who are undergoing dialysis. N Engl J Med. 2000;342(20):1478-83.

2. Shroff $R$, Long DA, Shanahan C. Mechanistic insights into vascular calcification in CKD. J Am Soc Nephrol. 2013:24(2):179-89.

3. Paloian NJ, Giachelli CM. A current understanding of vascular calcification in CKD. Am J Physiol Renal Physiol. 2014;307(8):F891-900.

4. Peacock M. Calcium metabolism in health and disease. Clin J Am Soc Nephrol. 2010:5(Suppl 1):S23-30.

5. Patel L, Bernard LM, Elder GJ. Sevelamer versus calcium-based binders for treatment of Hyperphosphatemia in CKD: a meta-analysis of randomized controlled trials. Clin J Am Soc Nephrol. 2016;11(2):232-44.

6. Cunningham J, Locatelli F, Rodriguez M. Secondary hyperparathyroidism: pathogenesis, disease progression, and therapeutic options. Clin J Am Soc Nephrol. 2011;6(4):913-21.

7. Fukagawa M, Yokoyama K, Koiwa F, Taniguchi M, Shoji T, Kazama JJ, Komaba H, Ando R, Kakuta T, Fujii H, et al. Clinical practice guideline for the management of chronic kidney disease-mineral and bone disorder. Ther Apher Dial. 2013;17(3):247-88

8. Wei $\mathrm{CH}$, Harari A. Parathyroid carcinoma: update and guidelines for management. Curr Treat Options in Oncol. 2012;13(1):11-23.

9. Silverberg SJ, Bone HG 3rd, Marriott TB, Locker FG, Thys-Jacobs S, Dziem G, Kaatz S, Sanguinetti EL, Bilezikian JP. Short-term inhibition of parathyroid hormone secretion by a calcium-receptor agonist in patients with primary hyperparathyroidism. N Engl J Med. 1997;337(21):1506-10.

10. Brown EM. Clinical lessons from the calcium-sensing receptor. Nat Clin Pract Endocrinol Metab. 2007:3(2):122-33.

11. Brennan SC, Thiem U, Roth S, Aggarwal A, Fetahu I, Tennakoon S, Gomes AR, Brandi ML, Bruggeman F, Mentaverri R, et al. Calcium sensing receptor signalling in physiology and cancer. Biochim Biophys Acta. 2013;1833(7): 1732-44.

12. Collins MT, Skarulis MC, Bilezikian JP, Silverberg SJ, Spiegel AM, Marx SJ. Treatment of hypercalcemia secondary to parathyroid carcinoma with a novel calcimimetic agent. J Clin Endocrinol Metab. 1998;83(4):1083-8.

13. Marcocci C, Cetani F, Rubin MR, Silverberg SJ, Pinchera A, Bilezikian JP. Parathyroid carcinoma. J Bone Miner Res. 2008;23(12):1869-80.

14. Raggi P, Chertow GM, Torres PU, Csiky B, Naso A, Nossuli K, Moustafa M, Goodman WG, Lopez N, Downey G, et al. The ADVANCE study: a randomized study to evaluate the effects of cinacalcet plus low-dose vitamin D on vascular calcification in patients on hemodialysis. Nephrol Dial Transplant. 2011;26(4):1327-39.

15. Sekercioglu N, Busse JW, Sekercioglu MF, Agarwal A, Shaikh S, Lopes LC, Mustafa RA, Guyatt GH, Thabane L. Cinacalcet versus standard treatment for chronic kidney disease: a systematic review and meta-analysis. Ren Fail. 2016;38(6):857-74
16. Bossola M, Tazza L, Ferrante A, Giungi S, Carbone A, Gui D, Luciani G. Parathyroid carcinoma in a chronic hemodialysis patient: case report and review of the literature. Tumori. 2005;91(6):558-62.

17. McClenaghan F, Qureshi YA. Parathyroid cancer. Gland Surg. 2015:4(4):329-38.

18. Tominaga Y, Kakuta T, Yasunaga C, Nakamura M, Kadokura Y, Tahara H. Evaluation of Parathyroidectomy for secondary and tertiary hyperparathyroidism by the parathyroid Surgeons' Society of Japan. Ther Apher Dial. 2016;20(1):6-11.

19. Levin KE, Galante M, Clark OH. Parathyroid carcinoma versus parathyroid adenoma in patients with profound hypercalcemia. Surgery. 1987;101(6): 649-60.

20. Stojadinovic A, Hoos A, Nissan A, Dudas ME, Cordon-Cardo C, Shaha AR, Brennan MF, Singh B, Ghossein RA. Parathyroid neoplasms: clinical, histopathological, and tissue microarray-based molecular analysis. Hum Pathol. 2003:34(1):54-64

21. Robert JH, Trombetti A, Garcia A, Pache JC, Herrmann F, Spiliopoulos A, Rizzoli R. Primary hyperparathyroidism: can parathyroid carcinoma be anticipated on clinical and biochemical grounds? Report of nine cases and review of the literature. Ann Surg Oncol. 2005;12(7):526-32.

22. Schantz A, Castleman B. Parathyroid carcinoma. A study of 70 cases. Cancer. 1973;31(3):600-5.

23. Shane E, Bilezikian JP. Parathyroid carcinoma: a review of 62 patients. Endocr Rev. 1982;3(2):218-26.

24. Hage MP, Salti I, El-Hajj Fuleihan G. Parathyromatosis: a rare yet problematic etiology of recurrent and persistent hyperparathyroidism. Metabolism. 2012:61(6):762-75.

25. Smith JF, Coombs RR. Histological diagnosis of carcinoma of the parathyroid gland. J Clin Pathol. 1984:37(12):1370-8.

26. Quinn CE, Healy J, Lebastchi AH, Brown TC, Stein JE, Prasad ML, Callender GG, Carling T, Udelsman R. Modern experience with aggressive parathyroid tumors in a high-volume New England referral center. J Am Coll Surg. 2015;220(6):1054-62.

27. Wynne AG, van Heerden J, Carney JA, Fitzpatrick LA. Parathyroid carcinoma: clinical and pathologic features in 43 patients. Medicine (Baltimore) 1992:71(4):197-205.

28. Bover J, Urena P, Ruiz-Garcia C, daSilva I, Lescano P, del Carpio J, Ballarin J, Cozzolino M. Clinical and practical use of Calcimimetics in dialysis patients with secondary hyperparathyroidism. Clin J Am Soc Nephrol. 2016;11(1):161-74.

29. National Kidney Foundation. K/DOQI clinical practice guidelines for bone metabolism and disease in chronic kidney disease.: Parathyroidectomy in patients with CKD. Am J Kidney Dis. 2003;42(Suppl 3):S127-9.

30. Moorthi RN, Moe SM. CKD-mineral and bone disorder: core curriculum 2011. Am J Kidney Dis. 2011;58(6):1022-36.

31. Fukagawa M, Fukuma S, Onishi Y, Yamaguchi T, Hasegawa T, Akizawa T, Kurokawa K, Fukuhara S. Prescription patterns and mineral metabolism abnormalities in the cinacalcet era: results from the MBD-5D study. Clin J Am Soc Nephrol. 2012;7(9):1473-80.

\section{Submit your next manuscript to BioMed Central and we will help you at every step:}

- We accept pre-submission inquiries

- Our selector tool helps you to find the most relevant journal

- We provide round the clock customer support

- Convenient online submission

- Thorough peer review

- Inclusion in PubMed and all major indexing services

- Maximum visibility for your research

Submit your manuscript at www.biomedcentral.com/submit
) Biomed Central 